\title{
Local public broadband - the missing link in Australia’s broadband debate?
}

\author{
Ian McShane ${ }^{\mathrm{a}}$ \\ ${ }^{a}$ Centre for Urban Research, RMIT University, ian.mcshane@rmit.edu.au
}

\begin{abstract}
The role of local government in providing public broadband has received little attention in Australian policy debate over broadband futures. The marginal position of the Australian local government sector in broadband debates both understates local initiatives and constrains our understanding of broadband as twenty-first century civic infrastructure. Local authorities provide Australia's public internet safety net through their funding of public internet in local libraries. There is a history of experimentation with local networks in underserved regions. Several city governments, including Adelaide, are investigating public Wi-Fi networks to boost social and economic vitality, and assist with urban management. Yet, Australia lags behind many other countries in providing broadband as a local public good. Drawing on international and Australian developments in local public broadband, this paper analyses rationales, opportunities and constraints for Australian local authorities in this field.
\end{abstract}

\section{Introduction}

Broadband is described as essential civic infrastructure of the twenty-first century (Greco 2010), yet Australian local authorities have taken few initiatives to provide it as a local public good, similar to physical facilities and community services. This situation contrasts with local initiatives in many other countries. In Europe and North America, for example, city governments are routinely involved in broadband provision, as a freely available public good, through subsidised schemes, or on a fully commercial basis (Broadband Communities 2012; Troulos \& Maglaris 2011). Internationally, the involvement of municipal authorities in providing fixed line or wireless broadband within their jurisdictions has been vigorously debated (Hauge et al. 2008). In Australia, the idea that digital inclusion might also include provision of local public broadband has barely registered in national broadband debates.

Signs of change, though, can be seen in the provision of WiFi on public transport (Cities of Brisbane, Adelaide), in city parks (Brisbane), and in retail strips (City of 
Darebin, inner Melbourne). Adelaide is currently investigating public WiFi provision across its central business district. Australians who can afford to travel internationally are becoming accustomed to the amenity of public WiFi. This is likely to translate into consumer or voter demand for local provision in Australia, a country with relatively high broadband and data costs. Indeed, the promise of 'free' WiFi now features in local government election platforms. ${ }^{1}$ However, municipal initiatives in this field have a mixed record in some countries. While the association of local-level physical and digital infrastructure seems increasingly intuitive to some, it has proven difficult to achieve in political, policy and commercial terms.

In Australia, political and public debate has focussed on the rollout of the National Broadband Network (NBN). There has been particular attention to technology choice, cost and roll-out, with 'last mile' delivery to households and business premises a point of disagreement between Australia's two major political parties. Intergovernmental agreements around NBN rollout have assigned the local government sector roles in planning and facilitating installation, and aggregating and promoting uptake. NBN's rollout timetable and fibre network coverage has prompted the formation of the advocacy group Broadband Today ${ }^{2}$, with a core membership of 120 local authorities. There has also been debate over whether local authorities are prepared to follow the example of some international counterparts (for example Scotland) and co-invest in network buildout (Taylor 2013; National Broadband Network Company 2012).

However, when viewed internationally, Australia's 'demand side' focus is a restricted one. Supply side questions - whether local authorities provide public access to networks and under what terms - are little explored. I am not suggesting that Australian local authorities set up as broadband retailers. Internationally, municipal entrepreneurialism in this field has been contested by higher governments and regulatory authorities, incumbent telcos, and residents. In Australia, such a move would fly in the face of established governance and public utility arrangements, invite regulatory scrutiny, and raise questions about local authority capacity and sustainability (Purser 2011).

There is a paradox at the heart of this topic though. Australian local authorities are important institutions in Australia's digital society: the nation's public internet system is hosted by municipal public libraries. There is a case for debating whether that role should extend to providing public access to broadband, supplementing what commercial providers make available, and supporting local government responsibilities in social and economic participation, community service provision and urban management.

\footnotetext{
${ }^{1}$ For example, public WiFi was included in candidate platforms in the City of Melbourne and City of Moonee Valley electorates during the 2012 Victorian local government elections.

${ }^{2}$ See $<$ http://www.broadbandtoday.com.au/>.
} 
This paper contextualises and contributes to that debate by (1) discussing international developments in local broadband, (2) summarising Australia's history in this area, and (3) identifying some policy and strategic issues regarding local government participation in the wider broadband ecology.

\section{Municipal broadband internationally}

Internationally, municipal or city governments have experimented with a range of local broadband platforms and business models for around two decades, giving rise to the term 'municipal broadband' in the literature (Middleton 2007). The term does not fully capture the range of locally oriented broadband models, which include community wireless networks, and new players such as Google and GigU. Google’s entry into local fibre network installation sparked a bidding war amongst US cities $^{3}$, while its Project Loon opens a new technological frontier in using high-altitude balloons to deliver remote connectivity. ${ }^{4}$ GigU, on the other hand, is a cooperative venture opening up local community access to the fibre networks of over 30 participating universities. ${ }^{5}$ The term 'bottom-up broadband' is increasingly used to describe diverse and participatory approaches to local networks and connectivity, some of which involve municipal or higher government support (Feser 2007; also see Gans 2007 for an Australian perspective).

Focussing on local government, Troulos and Maglaris (2011) argue that the key determinants of municipal ventures in broadband across the globe are the structure of telecommunications markets and regulatory policies, traditions of public intervention, and the historical role of municipalities in urban planning and utility provision. The extensive international literature in this field identifies several rationales for municipal involvement in broadband networks:

- equity and digital inclusion, particularly in cases of market or higher government failure

- infrastructure and service efficiencies (e.g. leveraging existing utility infrastructure and business assets)

- civic engagement and community building

- economic development and local innovation

\footnotetext{
${ }^{3}$ See $<$ https://fiber.google.com/about/>.

${ }^{4}$ See $<$ http://www.google.com/loon/>.

${ }^{5}$ See $<$ http://www.gig-u.org $>$.
} 
- urban competitiveness and 'creative class' theory (Van Oost et al. 2011; Troulos \& Maglaris 2011; Tapia et al. 2011; Middleton 2007; Matson \& Mitchell 2006; Gillett et al. 2004).

The development of WiFi standards in the late 1990s was a particular spur to local network development. Municipal interest in WiFi was initiated in many cases through an exploration of the technology's contribution to municipal services (Powell \& Shade 2006). Broadband and mobile technologies were viewed as enablers of role sharing between local officials and residents in areas such as asset and emergency management, and community services. In some instances, the primary argument for initial city investment was framed in terms of security and public safety (Jassem 2010).

Some analysts argue there has been insufficient public debate over the rationales, forms of provision and futures of municipal broadband. Criticisms are made on several grounds:

- quality of service (especially prevalent with WiFi networks)

- unsustainability of business models

- mismatch with user needs

- political and commercial risk, including the inability to transfer risk in 'pri-fi' metro networks that are largely driven by commercial interests

- exclusiveness of some community wireless networks

- a high correlation between the construction of municipal networks and existing high levels of broadband uptake suggests patterns of exclusion are reproduced rather than overcome (Community Broadband Networks 2012; Hartmann 2009; Middleton 2007; Fuentes-Battista 2006; Sandvig 2004).

Evaluations of municipal broadband networks have pointed to their benefits for city economies, although the published literature in this area is not robust (Ford \& Koutsky 2005; Standish, Boting \& Thompson 2007). Middleton (2007) is sceptical of investment arguments framed in terms of the digital divide, suggesting, in the North American context at least, that increased competition amongst commercial providers of 3G and 4G networks may benefit low-income earners more than municipal investment in broadband.

Alternatively, over-ambitious projections for local broadband connectivity and growth, particularly in disadvantaged areas, have proved fatal to network sustainability (Troulos \& Maglaris 2011; Middleton 2007). Rolling out demonstration projects or targeting low-income areas may result in low uptake and apparent lack of success. Powell and Shade (2006) observe that the sustainability of community networks in Canada has been threatened by the application of narrow performance criteria such as 
cost-covering, rather than broader, if less tangible assessments of the value of these networks.

Within a few years of municipal experimentation with broadband, Matson and Mitchell (2006) observed an emerging partnership model - between local authorities and commercial providers and/or not-for-profits - in local network provision. This model has proven broadly acceptable to regulators, although it has not found universal approval with local taxpayers. Pro-market adherents have cited the collapse of metro WiFi initiatives in several US cities as proof of the wider failure of the public broadband concept (Community Broadband Networks 2012). That view is countered by many examples of successful local ventures in network and broadband service provision.

\section{Australian developments}

Australian local government involvement in broadband provision has been strongly influenced by the dynamics of national government telecommunication and digital policy. This involvement can be roughly divided into three phases:

- a period of experimentation following telecommunications deregulation and the public release of WWW (1995-2005)

- a wait-and-see period following announcement of plans for a national broadband network (2005-2010)

- renewed interest in local broadband (2010+).

The period 1995-2005 saw local experimentation in this area, responding to concerns over liberalization of the telecommunications market (particularly its perceived threat to rural services) and exploring new opportunities presented by it. Ventures included the establishment of local telco networks, installation of fibre circuits, and several trials of WiFi and WiMax technologies. At least four electricity supply companies experimented with broadband over powerlines, conducting small-scale trials in metropolitan and country areas (Molony 2006). Other ventures investigated the particular technological, economic and cultural issues surrounding the delivery of telecommunications to remote Indigenous communities (Rennie et al. 2010). By 2005, much of this municipal experimentation appeared to have ceased. Australia missed the international wave of municipal WiFi network construction in the mid-2000s. The Australian government's 2004 National Broadband Strategy (NBS) now dominated the policy landscape, and commentators pointed to the commercial risks presented by a rapidly evolving telecommunications landscape (Braue 2008). 
Some Australian local authorities sought to locate future investment decisions within a wider digital strategy, consistent with the direction of national and state governments. The rhetoric of 'smart city' and 'connected community' is sprinkled liberally through these documents (for example, Parramatta City Council 2010). Several quasi-public developments, for example Melbourne’s Federation Square and Perth's Northbridge area (City of Perth 2010), paralleled the restricted WiFi provision of commercial premises such as McDonalds and Starbucks. Some Australian councils have partnered with community sector organisations to extend broadband connectivity. Three Melbourne municipalities (Yarra, Whitehorse and Darebin) joined with the not-for-profit InfoXchange to provide subsidised broadband and, in some cases, computer equipment and training to tenants on public housing estates and low-income residents. InfoXchange styles the initiatives on public housing estates in terms of digital inclusion (Meredyth et al. 2006), where the City of Darebin's initiative also describes broadband as an essential utility and component of city infrastructure (Greco 2010).

A number of municipalities have sought to extend public library WiFi networks, particularly where libraries are located in civic centres or plazas. However, the Australian Library and Information Association's (2011) most recent survey of public library internet services points to the limitations of library-based provision, in terms of available space for internet terminals, computer and staff resources, bandwidth and budgets. Australian public libraries and educational institutions do not enjoy broadband subsidies such as the US government's 'e-rate'. A recommendation by a 2003 Australia Senate inquiry into libraries to introduce such a scheme was rejected by the Australian government in favour of market competition as a means for delivering cheaper broadband (Australian Government Minister for Communications, Information Technology and the Arts 2004, p. 6). Rather, market failure was a principal reason for the design of NBN as a state-delivered project. There is little doubt that NBN marks a transformative moment for Australia's society and economy. However, the Australian Local Government Association’s (2012) 'broadband vision‘ canvasses limited options for municipal and local community initiative.

\section{Thinking about local broadband}

How we conceptualise broadband influences the terms of government intervention, the dimensions of market provision, and the role of citizens. The final part of this paper briefly discusses some conceptual and policy settings that underpin broadband provision, and highlights some strategic implications for Australian local authorities. 
Broadband policy in most parts of the globe views the electro-magnetic spectrum as a scarce or rivalrous resource, and its use is apportioned and managed through nationally regulated markets. The sale of the spectrum for mobile telephony is perhaps the clearest example of this institutional framework. The large capital outlays of mobile providers for exclusive use of spectrum bandwidth, and the revenue obtained by governments through spectrum auctions, give both an interest in protecting the market and suggests one reason why commercial and higher government interests have been so keen to litigate and legislate against municipal WiFi provision in the USA.

However, the relationship between market providers and municipal governments is rapidly evolving from perceived competition to cooperation as an increasing number of people access the internet through mobile devices. As recent developments in the UK indicate, a strategic rather than a competitive relationship is developing between the sectors as telcos seek to minimize congestion in 3G and 4G networks by subsiding local authorities to set up public WiFi networks, and paying for the use of local infrastructure assets for base station and antennae installations (Marshall 2013).

Frischmann (2012) argues that 'infrastructure' is any intermediate input that produces downstream economic and social value. 'Upstream' infrastructure decisions have significant 'downstream' consequences. Policy framing the ownership, management and access to infrastructure resources such as broadband and the internet is a significant 'upstream' decision. As it stands, municipal involvement in local broadband in many parts of the globe is strongly correlated with utility provision. Since Australian councils are generally not in the utility business, the rhetoric of broadband as a 'fourth utility', while raising important questions of access rights, underlines the role of higher governments in organizing universal public services, through direct provision or market regulation.

From a local service perspective, though, distinctions between physical and digital infrastructure are increasingly redundant in the provision of local services and management of the local public realm. Digital networks are essential to urban management and governance in areas such as transport, environmental management, emergency services, security, and resident consultation. Geo-location and mobile devices help residents and visitors navigate, learn about, co-manage and connect in physical space. Material and virtual worlds, and the roles and activities of local officials and local residents, are increasingly enmeshed. However, effective access and the production of relevant local content are pre-requisite inputs for such forms of engagement.

The widening role of Australian local authorities in community service provision raises important questions about digital inclusion. Public WiFi or public internet 
terminals may be the only effective access that poor or homeless people have to the internet. While there is almost universal broadband access in Australia's more affluent households, almost four in ten of the lowest income group - the population cohort most reliant on local public services - do not have home broadband (Ewing \& Thomas 2012; Morsillo 2012). Digital disconnection is associated with other factors of disadvantage that may have complex causes and require multi-level solutions, many of which will involve local government intervention (Eynon \& Geniets 2012; Newman et al. 2010). Alternatively, are expectations that local authorities will be the prime respondents to concerns over digital exclusion from a nationally regulated market a new instance of down-shifting or cost-shifting?

However, as Powell (2009) argues, what if we also thought of broadband as a public park, as well as a public utility? The metaphor suggests a meeting place, play space, a place for community dialogue, enjoyment, social learning and activism. This metaphor locates public broadband provision firmly within the remit of the local government sector. Benkler's (2002) argument for a wireless commons, an unregulated spectrum freely open to use, moves beyond public goods theory and the provisioning role of government. Benkler draws on innovation economics to argue for the social and economic significance of open source and co-operative experimentation in the digital environment. In Australia there are few connections between local authorities and community wireless enthusiasts that might foster such initiatives. However, the increasing interest of local governments in the innovative uses of public data, seen in initiatives such as GovHack$^{6}$, heralds new opportunities for experimentation and innovation in the local public realm.

\section{References}

Australian Government Minister for Communications, Information Technology and the Arts 2004, Australian Government Response to the Report into Libraries in the Online Environment, Australian Government: Department of Regional Australia, Local Government, Arts and Sport, Canberra, viewed 12 September 2013, $<$ http://arts.gov.au/sites/default/files/pdfs/Australian_Government_response_to_the_S enate_Committee_Inquiry_into_Libraries_in_the_Online_Environment.pdf>.

Australian Library and Information Association (ALIA) 2011, ALIA Internet Access in Public Libraries Survey 2011, ALIA, Deaking, Australian Capital Territory, viewed

\footnotetext{
${ }^{6}$ See $<$ http://www.govhack.org $>$.
} 
12 September 2013, >http://www.alia.org.au/sites/default/files/documents/advocacy/ Internet.Access.Survey.2011.pdf>.

Australian Local Government Association 2012, Information Technology - The Role of Government, viewed 12 September 2013, <http://www.alga.asn.au/?ID=134\& Menu=44,64>.

Benkler, Y. 2002, 'Some Economics of Wireless Communications', Harvard Journal of Law and Technology, vol. 16, no. 1, pp. 25-83.

Braue, D. 2008, 'Shocking times for Aussie broadband over powerlines', ZD Net, viewed 8 March 2013, <http://www.zdnet.com/shocking-times-for-aussie-broadband-overpowerline-1339285857>

Broadband Communities 2012, Deployments Database, viewed 12 September 2013, $<$ http://www.bbpmag.com/search.php>.

City of Perth 2010, An Australian First as 4G Broadband Comes to the Northbridge Piazza, media release, City of Perth, Perth, 12 March.

Community Broadband Networks 2012, Wireless, viewed 12 September 2013, $<$ http://muninetworks.org/content/wireless $>$.

Eynon, R. \& Geniets, A. 2012, On the Periphery? Understanding Low and Discontinuing Internet Use Amongst Young People in Britain, Oxford Internet Institute, Oxford.

Ewing, S. \& Thomas, J. 2012, CCi Digital Futures - The Internet in Australia, ARC Centre of Excellence for Creative Industries and Innovation, Hawthorn.

Feser, E. 2007, 'Encouraging Broadband Deployment from the Bottom Up', Journal of Regional Analysis and Policy, vol. 37, no. 1, pp. 69-72.

Ford, G. \& Koutsky, T. 2005, 'Broadband and Economic Development: A Municipal Case Study from Florida', Review of Urban \& Regional Development Studies, vol. 17, no. 3, pp. 216-29.

Fuentes-Bautista, M. \& Inagaki, N. 2006, 'Reconfiguring Public Internet Access in Austin, TX - Wi-Fi's Promise and Broadband Divides', Government Information Quarterly, vol. 23, no. 2, pp. 404-34.

Gans, J. 2007, 'Looking Local on Broadband', Public Policy, vol. 2, no. 1, pp. 10-24.

Gillett, S., Lehr, W. \& Osorio, C. 2004, 'Local Government Broadband Initiatives', Telecommunications Policy, vol. 28, no. 7-8, pp. 537-58.

Greco, G. 2010, Municipal Networks - McArthur Fellowship Award Report, Municipal Association of Victoria, Melbourne.

Hartmann, M. 2009, 'The Changing Urban Landscapes of Media Consumption and Production', European Journal of Communication, vol. 24, no. 4, pp. 421-36. 
Hauge, J., Jamison, M. \& Gentry, R. 2008, 'Bureaucrats as Entrepreneurs: Do Municipal Telecommunications Providers Hinder Private Entrepreneurs?', Information Economics and Policy, vol. 20, no. 1, pp. 89-102.

Jassem, H. 2010, 'Municipal Wi-Fi: The Coda', Journal of Urban Technology, vol. 17, no. 2, pp. 3-20.

Marshall, R. 2013, 'London Councils Newham and Havering Exit Free WiFi Plans as Barnet and Islington Sign Up', V3.co.uk, viewed 13 September 2013, $<$ http://www.v3.co.uk/v3-uk/news/2268588/london-councils-newham-and-haveringpull-out-of-free-wifi-plans>.

Matson, M. \& Mitchell, R. 2006, Study On Local Open Access Networks For Communities and Municipalities, World Bank, Washington D.C.

Meredyth, D., Thomas, J., Ewing, S. \& Hopkins, L. 2006, Wired High Rise - A Community-based Computer Network, Swinburne Institute for Social Research, Hawthorn.

Middleton, C. 2007, 'A Framework for Investigating the Value of Public Wireless Networks', 35th Conference on Communication, Information and Internet Policy, Telecommunications Policy Research Conference, Arlington, Virginia.

Molony, R. 2006, Innovative Uses of Broadband by Local Government in Australia Discussion Draft, Australian Local Government Association, Canberra, viewed 13 September 2013, <http://unpan1.un.org/intradoc/groups/public/documents/apcity/unpan032534.pdf>.

Morsillo, R. 2012, 'Broadband Affordability in Australia: Looking Beyond Availability', Telecommunications Journal of Australia, vol. 62, no. 5, pp. 80.1-80.16.

National Broadband Network Co 2012, NBN Co Network Extension Policy, viewed 13 September 2013, <http://www.nbnco.com.au/assets/documents/network-extensionpolicy.pdf $>$.

Newman, L., Biedzrycki, K. \& Baum, F. 2010, 'Digital Technology Access and Use among Socially and Economically Disadvantaged Groups in South Australia', Journal of Community Informatics, vol. 6, no. 2, pp. 1-31.

Parramatta City Council 2010, Parraconnect to Explore Digital Opportunities, viewed 13 September 2013, <http://www.parracity.nsw.gov.au/your_council/news/media/ media_releases $2 / 2010 /$ june_ 2010/parraconnect_to_explore_digital_opportunities>.

Powell, A. 2009, Wi-Fi as Public Utility or Public Park? Metaphors for Planning Local Communication Infrastructure, Social Science Research Network Working Paper 
Series, SSRN, viewed 13 September 2013, <http://www.ssrn.com/abstract= 1330913>.

Powell, A. \& Shade, L. 2006, 'Going Wi-Fi in Canada: Municipal and Community Initiatives,' Government Information Quarterly, vol. 23, no. 3-4, pp. 381-403.

Purser, K. 2011, Using Social Media in Local Government - 2011 Survey Report, Australian Centre of Excellence in Local Government, University of Technology, Sydney.

Regional Telecommunications Independent Review Committee 2012, 2011-12 Regional Telecommunications Review, Australian Government, Canberra.

Rennie, E., Crouch, A., Thomas, J. \& Taylor, P. 2010, 'Beyond Public Access? Reconsidering Broadband for Indigenous Communities', Communications Policy and Culture, vol. 43, no. 1, pp. 48-69.

Sandvig, C. 2004, 'An Initial Assessment of Cooperative action in Wi-Fi Networking', Telecommunications Policy, vol. 28, no. 7-8, pp. 579-602.

Standish, B., Boting, A. \& Thompson, G 2007, The Economic Impact of a Metropolitan Broadband Network for the City of Cape Town, Strategic Economic Solutions, Cape Town.

Tapia, A., Kvasny, L. \& Ortiz, J. 2011, 'A Critical Discourse Analysis of Three US Municipal Wireless Network Initiatives for Enhancing Social Inclusion', Telematics and Informatics, vol. 28, no. 3, pp. 215-26.

Taylor, J. 2013, Regional Councils Want to Pay for Broadband: Turnbull, ZDNet, viewed 12 April 2013, <http://www.zdnet.com/au/regional-councils-want-to-pay-forbroadband-turnbull-70000139 $08 />$.

Troulos, C. \& Maglaris, V. 2011, ‘Factors Determining Municipal Broadband Strategies across Europe', Telecommunications Policy, vol. 35, no. 9-10, pp. 842-56.

Van Oost, E., Verhaegh, S. \& Outshoorn, N. 2011, 'Wi-Fi as Community-based Innovation', in W. Lemstra, W. Hayes \& J. Groenewegen (eds), The Innovation Journey of Wi-Fi - The Road to Global Success, Cambridge University Press, Cambridge, pp. 263-87. 